\title{
Factors Affecting the Milk Composition of Kosali Cow
}

\author{
Jyoti Sahu $^{1}$, D. Bhonsle ${ }^{1}$, Sharad Mishra ${ }^{1}$, V.N. Khune ${ }^{1}$ and A.K. Chaturvedani ${ }^{2 *}$ \\ ${ }^{1}$ Department of Livestock Production and Management, College of Veterinary Science and \\ Animal Husbandry, Anjora, Chhattisgarh Kamdhenu Vihshwavidyalaya, Durg, \\ Chhattisgarh-491001, India \\ ${ }^{2}$ ICAR- Indian Veterinary Research Institute, Izatnagar, Bareilly, Uttar Pradesh-243122, India \\ *Corresponding author
}

\section{A B S T R A C T}

\begin{tabular}{|l|}
\hline Ke y w o r d s \\
Kosali cow, Fat, \\
$\begin{array}{l}\text { Solid not fat, Total } \\
\text { solids, Protein, } \\
\text { Lactose }\end{array}$ \\
\hline Article Info \\
\hline $\begin{array}{l}\text { Accepted: } \\
\text { 20 July 2018 } \\
\text { Available Online: } \\
\text { 10 August } 2018\end{array}$ \\
\hline
\end{tabular}

The present study was conducted to determine the milk composition and to observe the effect of parity, stages of lactation, season and management on milk constituent traits of Kosali cow of Chhattisgarh. This study was conducted from January 2014 to July 2014 with 450 milk samples from 76 Kosali cows. The overall mean obtained for fat, solid not fat, total solids, protein and lactose percentage were $4.385 \pm 0.095 \%, 8.229 \pm 0.037 \%$, $12.614 \pm 0.107 \%, 2.975 \pm 0.013 \%$, and $4.469 \pm 0.021 \%$, respectively. In the present study it was found that effect of parity was significantly affected all the major milk constituents of Kosali cow, beside this different stages of lactation also significantly altered the milk protein percentage $(\mathrm{p}<0.01)$ and lactose percentage $(\mathrm{p}<0.05)$. In the present investigation, season had significantly $(\mathrm{p}<0.01)$ affected all the major milk constituents of kosali cow except total solids. The effect of management was found significant $(\mathrm{p}<0.01)$ on milk fat and total solid percentage only.

\section{Introduction}

In general Kosali cows are reared on grazing and offering paddy straw only. Whereas, in urban and semi urban areas this breed is rarely available and mostly reared in semi intensive farming system offering dry fodder with little concentrates. This breed is preferred in rural Chhattisgarh due to their capacity to tolerate heat. Therefore a comprehensive study is required to observe the status of milk production traits of Kosali so that further improvement in concerned breed can be recommended. Development of breeding programs for augmenting the milk production and changing milk composition require knowledge of the relative influence of genetic and environmental factors affecting milk constituents. Hence, the present study was carried out to find out the effect of various factors like parity, stage of lactation, season and management on fat, solid not fat, total solid, protein, and lactose percentage of milk in Kosali cows.

\section{Materials and Methods}

The data for present study were collected from the farmers of urban area of Bhilai and village Bohardeeh under Durg district. A total of 76 
cows (54 from urban area and 22 from rural area) were selected and 20-25 ml of milk samples was collected for analysis of milk constituents. The samples of morning milking were drawn at weekly interval for a period of six months. In this way a total of 450 aliquots were collected for laboratory analysis of milk by using Milkotester, model LM2.

\section{Classification of data}

The milk samples were collected from the cows with parties varied from $1^{\text {st }}$ to $4^{\text {th }}$ order of lactation. According to the climate of Chhattisgarh state, January and February was considered as winter; April and May as summer and June and July as rainy season. Lactation period was classified as early stage (5 to 90 days), mid stage (91 to 180 days) and late stage (above 181 days).

On the basis of management practices the animals were grouped into rural area and urban area. In rural area most of the Kosali cows are reared in extensive system of farming where these cows are fed by grazing and dry paddy straw only. Whereas, in urban areas Kosali cows are maintained in semi intensive system of farming and along with dry fodder they also get some concentrates.

\section{Statistical analysis}

Statistical analysis of the data was conducted using least-square analysis of variance (Harvey 1966). Individual mean comparisons were made for the significant effect using the formula given by Snedecor and Cochran (1994).

\section{Results and Discussion}

The overall least square means for fat, solid not fat, total solids, protein, lactose percentage and test day milk yield of Kosali cows were found to be $4.385 \pm 0.095 \%, 8.229 \pm 0.037 \%$,
$12.614 \pm 0.107 \%, 2.975 \pm 0.013 \%, 4.469 \pm 0.021 \%$, $1.271 \pm 0.041 \mathrm{~kg}$, respectively.

\section{Effect of parity}

Parity has significantly affected all the major milk constituents (Table 1). The effect of parity was highly significant $(\mathrm{P}<0.01)$ on milk fat percentage. In the present study, the mean fat percentage among $1^{\text {st }}, 2^{\text {nd }}$ and $3^{\text {rd }}$ parities differed significantly $(\mathrm{p}<0.01)$ from each other whereas in the $4^{\text {th }}$ parity it was intermediate between $2^{\text {nd }}$ and $3^{\text {rd }}$ parity (Table 1 ). Highest fat percentage was found in the $1^{\text {st }}$ parity which gradually decreased to $3^{\text {rd }}$ parity afterwards it slightly increased in the $4^{\text {th }}$ parity. This trend was similar to the findings reported by Kayastha et al., (2008) for native cattle of Assam.

\section{Solid not fat (SNF)}

The SNF percentage was significantly $(\mathrm{p}<0.05)$ influenced by the effect of parity. Similarly, Sudhakar et al., (2013) reported significant effect of parity on milk SNF percentage. In the present study, the mean differences between $1^{\text {st }}, 2^{\text {nd }}$ and $3^{\text {rd }}$ parities were non-significant however, it was significantly $(\mathrm{p}<0.05)$ highest in the $4^{\text {th }}$ parity.

\section{Total solids (TS)}

The effect of parity was found highly significant $(\mathrm{P}<0.01)$ on total solids percentage. This was closely related to the report of Venkatchelapathy (1998) in Vechur cows. In contrast Sarkar et al., (2006) and Kayastha et al., (2008) observed non-significant effect of parity in total solids percentage. Highest mean for TS percentage was recorded in the $1^{\text {st }}$ parity followed by $2^{\text {nd }}$ and lowest in the $3^{\text {rd }}$ parity and afterwards again increased in the $4^{\text {th }}$ parity. However, the differences between the mean total solids percentage in the $2^{\text {nd }}$ and $4^{\text {th }}$ parities were non- significant. Since, the fat 
percentage is a major component of total solids, therefore the parity trend for total solids was similar to the trend of fat.

\section{Protein}

Parity had significant $(\mathrm{P}<0.05)$ effect on milk protein percentage (Table 1). The differences between $1^{\text {st }}, 2^{\text {nd }}$, and $3^{\text {rd }}$ parities were nonsignificant, however it was significantly higher in the $4^{\text {th }}$ parity.

Although significant effect of parity on milk protein percentage has also been elucidated by Sudhakar et al., (2013). Whereas, Gurmessa et al., (2012) and Krovvidi et al., (2013) reported non-significant effect of parity in milk protein percentage.

\section{Lactose}

The effect of parity was found significant $(\mathrm{P}<0.05)$ on milk lactose percentage of Kosali cow (Table 1). In contrast, non-significant effect of parity on lactose was reported by Sudhakar et al., (2013) and Krovvidi et al., (2013).

In the present study the mean lactose percentage decreased from $1^{\text {st }}$ to $3^{\text {rd }}$ parity but the differences were non-significant, afterwards increased significantly $(\mathrm{p}<0.05)$ in the $4^{\text {th }}$ parity.

\section{Effect of seasons}

All the major milk constituent traits were significantly $(\mathrm{p}<0.01)$ affected by seasons except total solids (Table 3). Season had significantly $(\mathrm{p}<0.01)$ affected the milk fat percentage of Kosali cow.

This is in close agreement with the reports of Bahaswan (2014). Contrary to this, Sarkar et al., (2006) observed non-significant effect of season on milk fat percentage.

\section{Solid not fat (SNF)}

The effect of season on milk SNF percentage of Kosali cows was highly significant $(\mathrm{P}<0.01)$. Suman et al., (2009) also reported significant effect of season on milk SNF percentage in crossbred cows. In the present study the mean SNF percentage was significantly $(\mathrm{P}<0.01)$ higher in winter season followed by summer and lowest in the rainy season.

It could be attributed due to availability of adequate quality and quantity of green fodder in the winter season. However, the mean differences of SNF percentage between the summer and rainy season were nonsignificant. Similar trend was also reported by Sharma et al., (2002) as they observed highest SNF percentage in winter and lowest in rainy season among crossbred cows.

\section{Protein}

All the seasons significantly $(\mathrm{P}<0.01)$ influenced the milk protein percentage of Kosali cows (Table 3). Similarly Sarkar et al., (2006) reported significant effect of season on milk protein percentage in Sahiwal, Tharparkar and Karan Fries cows. The least square mean for protein percentage was significantly $(\mathrm{p}<0.01)$ highest in the winter season followed by summer and lowest in the rainy season. However, the mean differences between summer and rainy season were nonsignificant. In the present study, significantly higher level of protein percentage in winter season could be attributed to better availability of quality green fodder during winter season as compared to that of summer season.

\section{Lactose}

The influence of season was highly significant $(\mathrm{P}<0.01)$ on milk lactose percentage in Kosali cows. 
Table.1 Effect of parity on major milk constituents and test day milk yield

\begin{tabular}{|l|c|c|c|c|c|c|c|}
\hline $\begin{array}{c}\text { No. of } \\
\text { observation }\end{array}$ & Fat \% & SNF \% & TS\% & $\begin{array}{c}\text { Protein } \\
\%\end{array}$ & $\begin{array}{c}\text { Lactose } \\
\%\end{array}$ & $\begin{array}{c}\text { TDMY } \\
\mathrm{kg}\end{array}$ \\
\hline First & 151 & 4.984 & $8.175 \pm$ & $13.158 \pm$ & $2.971 \pm$ & $4.461 \pm$ & $1.352 \pm$ \\
parity & $10.129^{\mathrm{c}}$ & $0.050^{\mathrm{a}}$ & $0.145^{\mathrm{c}}$ & $0.017^{\mathrm{a}}$ & $0.028^{\mathrm{a}}$ & $0.056^{\mathrm{a}}$ \\
\hline Second & 102 & $4.424 \pm$ & $8.183 \pm$ & $12.607 \pm$ & $2.961 \pm$ & $4.448 \pm$ & $1.277 \pm$ \\
parity & & $0.137^{\mathrm{b}}$ & $0.053^{\mathrm{a}}$ & $0.154^{\mathrm{b}}$ & $0.018^{\mathrm{a}}$ & $0.030^{\mathrm{a}}$ & $0.059^{\mathrm{a}}$ \\
\hline Third & 105 & $3.919 \pm$ & $8.158 \pm$ & $12.077 \pm$ & $2.939 \pm$ & $4.413 \pm$ & $1.097 \pm$ \\
parity & & $0.146^{\mathrm{a}}$ & $0.057^{\mathrm{a}}$ & $0.164^{\mathrm{a}}$ & $0.020^{\mathrm{a}}$ & $0.032^{\mathrm{a}}$ & $0.063^{\mathrm{a}}$ \\
\hline Fourth & 92 & 4.211 & $8.402 \pm$ & $12.614 \pm$ & $3.030 \pm$ & $4.554 \pm$ & $1.356 \pm$ \\
parity & & $\pm 0.194^{\mathrm{ab}}$ & $0.076^{\mathrm{b}}$ & $0.218^{\mathrm{b}}$ & $0.026^{\mathrm{b}}$ & $0.043^{\mathrm{b}}$ & $0.084^{\mathrm{b}}$ \\
\hline
\end{tabular}

The values with different superscripts in the same columns differ significantly from each other. SNF=Solid Not Fat, TS=Total Solids, TDMY = Test Day Milk Yield.

Table.2 Effect of stages of lactation on major milk constituents and test day milk yield

\begin{tabular}{|l|c|c|c|c|c|c|c|}
\hline $\begin{array}{l}\text { Stages of } \\
\text { lactation }\end{array}$ & $\begin{array}{c}\text { No. of } \\
\text { observation }\end{array}$ & Fat \% & SNF \% & TS \% & $\begin{array}{c}\text { Protein } \\
\%\end{array}$ & $\begin{array}{c}\text { Lactose } \\
\%\end{array}$ & $\begin{array}{c}\text { TDMY } \\
\text { kg }\end{array}$ \\
\hline Early & 143 & $4.262 \pm$ & $8.282 \pm$ & $12.544 \pm$ & $2.989 \pm$ & $4.513 \pm$ & $1.313 \pm$ \\
\hline stage & & 0.166 & 0.064 & 0.187 & $0.022^{\mathrm{b}}$ & $0.036^{\mathrm{b}}$ & $0.072^{\mathrm{b}}$ \\
\hline Mid stage & 179 & $4.495 \pm$ & $8.141 \pm$ & $12.635 \pm$ & $2.933 \pm$ & $4.416 \pm$ & $1.458 \pm$ \\
& & 0.122 & 0.047 & 0.137 & $0.016^{\mathrm{a}}$ & $0.027^{\mathrm{a}}$ & $0.053^{\mathrm{c}}$ \\
\hline Late stage & 128 & $4.397 \pm$ & $8.265 \pm$ & $12.662 \pm$ & $3.004 \pm$ & $4.478 \pm$ & $1.042 \pm$ \\
& & 0.183 & 0.071 & 0.205 & $0.025^{\mathrm{c}}$ & $0.040^{\mathrm{a}}$ & $0.079^{\mathrm{a}}$ \\
\hline
\end{tabular}

Table.3 Effect of seasons on major milk constituents and test day milk yield

\begin{tabular}{|l|c|c|c|c|c|c|c|}
\hline Season & $\begin{array}{c}\text { No. of } \\
\text { observation }\end{array}$ & Fat \% & SNF \% & TS \% & $\begin{array}{c}\text { Protein } \\
\%\end{array}$ & $\begin{array}{c}\text { Lactose } \\
\%\end{array}$ & $\begin{array}{c}\text { TDMY } \\
\text { kg }\end{array}$ \\
\hline Winter & 148 & 4.009 & $8.656 \pm$ & $12.665 \pm$ & $3.129 \pm$ & $4.693 \pm$ & $1.470 \pm$ \\
& & $\pm 0.164^{\mathrm{a}}$ & $0.063^{\mathrm{b}}$ & 0.184 & $0.022^{\mathrm{b}}$ & $0.036^{\mathrm{c}}$ & $0.071^{\mathrm{c}}$ \\
\hline Summer & 171 & 4.103 & $8.262 \pm$ & $12.364 \pm$ & $2.980 \pm$ & $4.491 \pm$ & $1.359 \pm$ \\
& & $\pm 0.113^{\mathrm{a}}$ & $0.044^{\mathrm{a}}$ & 0.127 & $0.015^{\mathrm{a}}$ & $0.025^{\mathrm{b}}$ & $0.049^{\mathrm{b}}$ \\
\hline Rainy & 131 & 5.042 & $7.771 \pm$ & $12.813 \pm$ & $2.818 \pm$ & $4.223 \pm$ & $0.983 \pm$ \\
& & $\pm 0.218^{\mathrm{b}}$ & $0.085^{\mathrm{a}}$ & 0.245 & $0.029^{\mathrm{a}}$ & $0.048^{\mathrm{a}}$ & $0.094^{\mathrm{a}}$ \\
\hline
\end{tabular}

Table.4 Effect of management on major milk constituents and test day milk yield

\begin{tabular}{|l|l|l|l|l|l|l|l|}
\hline Management & $\begin{array}{c}\text { No. of } \\
\text { observation }\end{array}$ & \multicolumn{1}{|c|}{ Fat \% } & $\begin{array}{c}\text { SNF } \\
\%\end{array}$ & \multicolumn{1}{|c|}{ TS \% } & $\begin{array}{l}\text { Protein } \\
\%\end{array}$ & $\begin{array}{l}\text { Lactose } \\
\%\end{array}$ & $\begin{array}{c}\text { TDMY } \\
\text { kg }\end{array}$ \\
\hline Urban area & 152 & 4.097 & 8.199 & $12.296 \pm$ & $2.975 \pm$ & $4.462 \pm$ & $1.756 \pm$ \\
& & $\pm 0.146^{\mathrm{a}}$ & 0.056 & $0.164^{\mathrm{a}}$ & 0.020 & 0.032 & $0.063^{\mathrm{b}}$ \\
\hline Rural area & 298 & 4.673 & 8.260 & $12.932 \pm$ & $2.976 \pm$ & $4.476 \pm$ & $0.785 \pm$ \\
& & $\pm 0.107^{\mathrm{b}}$ & 0.041 & $0.120^{\mathrm{b}}$ & 0.014 & 0.023 & $0.046^{\mathrm{a}}$ \\
\hline
\end{tabular}


Similar findings was also observed by Painkra (2007) who found significant effect of season on lactose percentage of milk in Sahiwal cows. Whereas, Bahashwan (2014) reported non-significant effect of season on milk lactose percentage of Dhofari cows.

In the present study the mean lactose percentage was found significantly higher in the winter season than summer season and lowest in the rainy season. This is in close agreement with the findings of Painkra (2007) who reported highest lactose percentage in spring season followed by pre monsoon season and lowest in the summer season. In the present investigation higher value of milk lactose percentage during winter season could be attributed due to better availability of green fodder and adequate grazing area during winter season as compared to summer and rainy season.

\section{Total solid (TS)}

The effect of season was non-significant on milk total solid percentage of Kosali cows (Table 3). The least square means of TS was lowest in the summer season afterwards slightly increased in winter season and came to highest level in the rainy season. The highest value of TS percentage in the rainy season was also observed by Sarkar et al., (2006). However, Sharma et al., (2002) found that the TS percentage of crossbred cows were higher in the winter followed by summer and lowest in the rainy season.

\section{Effect of stages of lactation}

Milk fat, solid not fat (SNF), and Total solids (TS) percentage were not affected significantly by stages of lactation in the present study. However, milk protein and lactose percentage were significantly influenced by stages of lactation in Kosali cows (Table 2).

\section{Fat}

In the present study the effect of stages of lactation were found to be non-significant. Similar findings were also reported by Sarkar et al., (2006). Contrary to this, Kayastha et al., (2008) and Gurmessa et al., (2012) reported significant effect of stages of lactation on milk fat percentage. In the present study highest fat percentage was recorded in the mid stage of lactation and lowest in the early stage of lactation but the differences were non-significant.

\section{Solid not fat (SNF)}

The effect of stages of lactation was nonsignificant on milk SNF percentage of Kosali cows. The present findings were in agreement with the reports of Sarkar et al., (2006), Gurmessa et al., (2012), Krovvidi et al., (2013), Sudhakar et al., (2013) and Pratap et al., (2014).

In the present study the SNF percentage in the early and late stage were higher as compared to mid stage of lactation. This trend was similar to the reports of Kayastha et al., (2008), Sudhakar et al., (2013) and Talukdar et al., (2013).

\section{Total solids (TS)}

In the present study the TS percentage was not affected significantly by stages of lactation.

In contrast, significant effect of stages of lactation on TS percent was reported by Sarkar et al., (2006), Kayastha et al., (2008) and Talukdar et al., (2013). Lowest value for mean TS percentage was found in the early stage of lactation followed by mid stage and highest in the late stage of lactation but the differences were non-significant in the milk of Kosali cows. 


\section{Protein}

The stages of lactation had significantly $(\mathrm{p}<0.01)$ affected the milk protein percentage of Kosali cows. Similar findings were also reported by Sarkar et al., (2006). However, Kayastha et al., (2008), Gurmessa et al., (2012), Sudhakar et al., (2013) and Krovvidi et al., (2013) found that mean protein percentage was not affected significantly by stages of lactation.

\section{Lactose}

The effect of stages of lactation was found to be significant $(\mathrm{p}<0.05)$ on milk lactose percentage of Kosali cows. Similar findings were reported by Sarkar et al., (2006). However, Gurmessa et al., (2012), Sudhakar et al., (2013) and Krovvidi et al., (2013) observed non-significant effect of stages of lactation for milk lactose percentage. In the present study the lactose percentage was significantly highest $(\mathrm{p}<0.05)$ in the early stage of lactation and lowest in the mid stage of lactation. However, the differences between mid and late stages of lactation were non-significant.

\section{Effect of management}

The effect of management was found to be significant $(\mathrm{p}<0.01)$ on milk fat percentage, total solids percentage and test day milk yield. In the present study the milk fat percentage and total solids percentage were significantly $(\mathrm{p}<0.01)$ higher in the rural area than in the urban area. Whereas, the test day milk yield was significantly higher $(p<0.01)$ in the urban area than in the rural area. This might be due to feeding of concentrates along with paddy straw to the cows reared in semi intensive system of farming in the urban area (Table 4).

All the factors under study i.e., effect of parity, stages of lactation, season and management on test day milk yield was highly significant suggesting that test day milk yield is very much influenced by nongenetic factors. The effect of parity on milk fat, SNF, protein, lactose, total solids was significant and had similar trend of decline from $1^{\text {st }}$ to $3^{\text {rd }}$ parity then rises in the $4^{\text {th }}$ parity. The effect of season was highly significant on milk fat, solid not fat, protein, lactose and test day milk yield. Highest milk production was obtained during winter which could be due to better availability of fodder in winter. Effect of management on milk fat, total solids, and test day milk yield is highly significant therefore it can be concluded that quantity of milk from Kosali cows can be improved by adopting better feeding and management practices.

\section{References}

Bahashwan S. (2014). Effect of cold and hot seasons on fat, protein and lactose of Dhofari cow's milk. Net Journal of Agricultural Science. 2(1): 47-49.

Gurmessa J. and Melaku A. (2012). Effect of lactation stage, pregnancy, parity and age on yield and major components of raw milk in bred cross Holstein Friesian cows. World Journal Dairy \& Food Science. 7(2): 146-49.

Harvey W. R. (1966). Least square analysis of data with unequal subclass number. United states Department of Agriculture, Washington.

Kayastha R. B., Zaman G. and Goswami R. N. (2008) Factors affecting the milk constituents of native cattle of Assam. Indian Journal Animal Research. 42(4): 270-72.

Krovvidi S., Panneerselvam S., Thriruvenkadan A. K., Rajeswar J. J., Sivakumar K. and Vinoo R. (2013). Lactation performance and milk constituents of Ongole cattle in its breeding tract. Research and Reviews: 
Journal of Veterinary Science and Technology. 2(2): 8-11.

Painkra S.K.S. (2007). Studies on milk composition of Sahiwal cows in Chhattisgarh. M.V.Sc. thesis submitted to Indira Gandhi Krishi Vishwavidyalaya, Raipur (C.G.).

Pratap A., Verma D. K., Kumar P. and Singh A. (2014). Effect of pregnancy, lactation stage, parity and age on yield and components of raw milk in Holstein Friesian cows in organised dairy farm in Allahabad. Journal of Agriculture and Veterinary Science (IOSR-JAVS) 7(2): $112-15$.

Sarkar U. Gupta A. K., Sarkar V., Mohanty T K, Raina V S and Prasad S. (2006). Factors affecting test day milk yield and milk composition in dairy animals. Journal Dairying, Foods \& Home science. 25(2): 129-32.

Sharma R. B., Kumar M. and Pathak V. (2002). Effect of different seasons on crossbred cow milk composition and paneer yield on Sub- Himalayan region. Asian- Australian Journal Animal Science. 15(4): 528-30.

Snedecor G. W. and Cochran W. G. (1989). Statistical methods. Oxford and IBH Publishing Company, New Delhi.

Snedecor G. W. and Cochran W. G. (1994). Statistical Methods. $8^{\text {th }}$ edn. Oxford and IBH Publishing Co., Kolkata.
Sudhakar K., Panneerselvam S., Thiruvenkadan A. K., Abraham J. and Vinodkumar G. (2013). Factors effecting milk composition of crossbred dairy cattle in southern India. International Journal of Food Agriculture and Veterinary Sciences. 3(1): 229-33.

Sudhakar K., Panneerselvam S., Thiruvenkadan A.K., Abraham J. and Vinodkumar G. (2013). Factors effecting milk composition of crossbred dairy cattle in southern India. International Journal of Food Agriculture and Veterinary Sciences. 3(1): 229-33.

Suman C. L. (2009). Lactation trend of milk solid not fat in two breed crosses of cattle at an organised farm. Indian Journal of Animal Research. 43(1): 1216.

Talukder M.A.I., Panandam J.M., Halimatun Y., and Idris I. (2013). Milk composition and quality of SahiwalFriesian crossbred cow studied in Malayasia. The Agriculturalists 11(2): 58- 65.

Venkatachelapathy, R. T. and Iype, S. (1998). Fat, total solids and solid not fat percentage of milk in Vechur cattle. Indian Journal of Animal Science. 68: 570.

\section{How to cite this article:}

Jyoti Sahu, D. Bhonsle, Sharad Mishra, V.N. Khune and Chaturvedani, A.K. 2018. Factors Affecting the Milk Composition of Kosali Cow. Int.J.Curr.Microbiol.App.Sci. 7(08): 37953801. doi: https://doi.org/10.20546/ijcmas.2018.708.387 